\title{
閉塞性腎症の基礎と臨床
}

東北大学大学院医学系研究科医科学専攻泌尿生殖器学講座泌尿器科学分野

\begin{tabular}{|c|c|c|c|c|}
\hline 石戸谷滋人 & 金藤 & 博行 ${ }^{1)}$ & 福崎 & 篤 ${ }^{2)}$ \\
\hline 尾形 幸彦 & 中川 & 晴夫 & 折笠 & 精—3) \\
\hline
\end{tabular}

\section{PATHOPHYSIOLOGY AND CLINICAL IMPLICATION OF OBSTRUCTIVE NEPHROPATHY}

\author{
Shigeto Ishidoya, Hiroyuki Kaneto ${ }^{1)}$, Atsushi Fukuzaki ${ }^{2}$, Atsushi Takeda, \\ Yukihiko Ogata, Haruo Nakagawa, Seiichi Orikasa ${ }^{3)}$ and Yoichi Arai \\ Department of Urology, Tohoku University Graduate School of Medicine \\ KANETO Nephro-Urology Clinic ${ }^{1)}$ \\ Department of Urology, Tohoku-Koseinenkin Hospital ${ }^{2)}$ \\ Sendai Shakaihoken Hospital ${ }^{3)}$
}

Obstructive nephropathy refers to the mechanical or functional changes in the urinary tract that interfere with normal urinary flow. Once obstruction is set, it leads to progressive renal damage that is mainly characterized with tubulointerstitial fibrosis. Here we reviewed the pathophysiology of urinary tract obstruction and indicated future therapeutic options.

Following complete unilateral ureteral obstruction, there is a progressive fall in renal blood flow and glomerular filtration rate, and is an increase in intratubular pressure. These events activate the plasma and tissue renin-angiotensin systems (RAS). It has been proved that upregulated angiotensin II is one of the crucial factors those are responsible for the subsequent deleterious process. Angiotensin II induces transforming growth factor- $\beta$, which causes overproduction of extracellular matrix (ECM) proteins like collagen, fibronectin, etc. The ECM proteins are dominantly accumulated in tubulointerstitium and result in deterioration of renal function. Along with the activation of the RAS, tissue ischemia and mononuclear leukocyte infiltration also modulate the fibrotic changes. The process from the RAS activation to renal fibrosis is observed not only in obstructive nephropathy but also in other renal diseases and is called the Final Common Pathway. Mechanical release of the obstruction is to perform in terms of the treatment, however, several promising pharmaceutical options are now under investigation.

Key words : obstructive nephropathy, tubulointerstitial fibrosis, angiotensin II

要旨: 泌尿器科における腎機能が廃絶していく疾患の中で, 尿路の通過障害即ち閉塞性腎症は大きな比 重を占めている，当教室では長年にわたりこの疾患の治療に携わると共に，その病態生理の解明に取り 組んできた. 現在までに明らかにされてきた事塞と我々が得た最近の知見とを併せて, 閉塞性腎症の進 展のメカニズムと新たな治療の可能性について概説した.

尿管に急性の完全閉塞が生ずると, 形態としてはまず水腎症を呈する. 内部では尿細管内圧, 組織内 圧が上昇，これが引き金となって腎組織のレニンーアンジオテンシン系(RAS)の活性化と虚血が生ずる.

\footnotetext{
1)現 かねとう腎泌尿器科クリニック

2)現＼cjkstart東北厚生年金病院泌尿器科

${ }^{3}$ 現 仙台社会保険病院
} 
増加したアンジオテンシン II は transforming growth factor- $\beta$ （TGF- $\beta$ ）の発現を充進させ，この TGF$\beta$ が collagen や fibronectin 等の細胞外基質を蓄積させる.こうして進行した尿細管間質の線維化が虚血 性変化と共に腎機能の低下を誘導していく，ヒトにおいては約 5 カ月の閉塞で機能はほぼ完全に㳖失す る. RAS の活性化以降のこの一連のプロセスは糖尿病性腎症や糸球体腎炎等の他の腎疾患においてもほ ぼ共通であることが判明, Final Common Pathway と称されるようになった.治療としては機械的な閉塞 の解除が第一選択であるが, この Pathway をブロックする薬剤による種々の試みもなされ, 期待されて いる.

キーワード：閉塞性腎症，尿細管間質線維化，アンジオテンシン II

はじめに

尿路の通過障害は先天奇形を初めとして，結石，尿 管腫瘍による閉塞，前立腺肥大症の他，骨盤腔や後腹 膜腔の腫瘍，子宮筋腫，胎児による圧排等によって生 ずる，日常的に遭遇することの多い病態である．形態 的には腎孟，腎杯の拡張として認められ，いわゆる水 腎症と称される疾患である．水腎症を放置すれば徐々 に腎実質が菲薄化していき，機能が廃絶していくこと は周知の事実であり，このような尿路の通過障害（閉 塞)に伴う腎障害を閉塞性腎症と定義している ${ }^{1)}$. 2001 年にはこの閉塞性腎症により 112 名が透析療法導入と なっている2．泌尿器科医はこの病態に対して腎孟形 成術を施したり腎瘻や内ステントを留置したりして, 外科的，機械的に対応してきた。当教室では閉塞性腎 症の発症と進展の機序について研究を蓄積して ${ }^{3) \sim 7)}$, 機会ある毎に発表報告してきた ${ }^{899)}$ 。しかし，最近の分 子生物学的な研究法の進歩と相まって徐々にその微細 な機序が解明され，それらの多くが他の腎疾患と共通 の側面を有することも分かってきた。本総説では，閉 塞性腎症に関する病態生理と, 我々が最近得た知見と を併せて論述する。

\section{臨床的側面}

閉塞が一側性か両側性か, 完全閉塞か不完全閉塞か, 急性閉塞か慢性閉塞かによって病態は大きく異なる。 ここでは急性の一側性完全閉塞について述べる.

一側尿路の完全閉塞の場合，どの程度の放置期間の 後に腎が不可逆性の変化を来すのかははっきりとは分 かっていない，動物実験でもヒト腎でもその病態，組 織像は尿細管間質の線維化と萎縮が主体で，糸球体の 構造は末期になるまで保たれていることが多い10)（図 1).ここで述べる間質の主たる構成成分は毛細血管と 線維芽細胞である．組織変化には当初は不均一性が認 められるが，閉塞が長期に渡って放置され不可逆的変 化を来たした腎では皮質が菲薄化し，その間質領域は collagen, laminin, fibronectin 等の細胞外基質蛋白で占

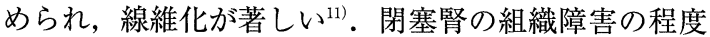
は一様でなく, 個々のネフロン間での不均一性が存在 する.その原因として, 各々のネフロンの輸出入動脈一 血流量がそもそも均一でなく，これに閉塞が加わるこ とによって血流量の低下したネフロンと比較的良好に 保たれたネフロンとの差異が顕在化してくるためと考 えられている ${ }^{12)}$.ラットの片側尿管を結紮したモデル （unilateral ureteral obstruction: UUO）を用いて数多 くの実験が成されてきたが，3 日間の完全閉塞の後に 開放すると, 濾過機能を有する機能的ネフロン数は $60 \%$ までしか回復しなかった ${ }^{13)}$. 5 日間の完全閉塞の 後に開放すると, 線維化して拡張した間質領域が全尿 細管間質領域に占める比率（間質ボリューム）は開放 後 4 週間でも完全には戻らない ${ }^{14)}$. ラットにおいては 3〜 5 日間の完全閉塞は腎実質に慢性的, 不可逆的な障 害を残すと思われる. Vaughan, Jr. と Gillenwater のイ 又を用いての有名な実験では閉塞 40 日後の解除で機 能は殆ど回復しなかった ${ }^{15)}$. ヒトでも臨床経験による 実感としてはほぼ同様と考えられるが，他科の手術に おいて誤って尿管を結紮した例が一つの参考となる. 我々は 157 日後に結紮部を解除した例を報告したが， この症例は結紮後より高血圧を合併し，患側腎機能は 殆ど回復しなかった ${ }^{16)}$ 。一方，片側完全閉塞 150 日， 153 日後に解除手術を行い, 経静脈性腎孟造影 (IVP) 上造影されるまでには回復した報告例もある ${ }^{1718)}$ 。し かしこれらは後述する尿細管, 腎孟等からの吸収の程 度が関連する特殊な例と考えられる。これら全ての臨 床報告例から考察すると，完全閉塞腎では早期から不 可逆的障害が徐々に進行し，これを rescue する適応は 5 カ月が一つの目安となりそうである。

\section{発症および進展機序}

健常者の腎孟内圧は $10 \mathrm{cmH}_{2} \mathrm{O}$ 以下である．急性の 一側性完全尿路閉塞発生後の生理学的変化は三相に分 けて説明される．まず第一相では腎血流量と尿管内圧 は共に上昇，この第一相の変化は $1 \sim 1.5$ 時間続く ${ }^{19)}$. 
四 1 完全閉塞 5 力月のCT と組織像

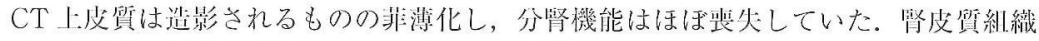
は, 糸球体の情築は保たれているものの㽷縕管閣質は萎縮し線維化が著しい（AzanMallory 染色 200 㒄).
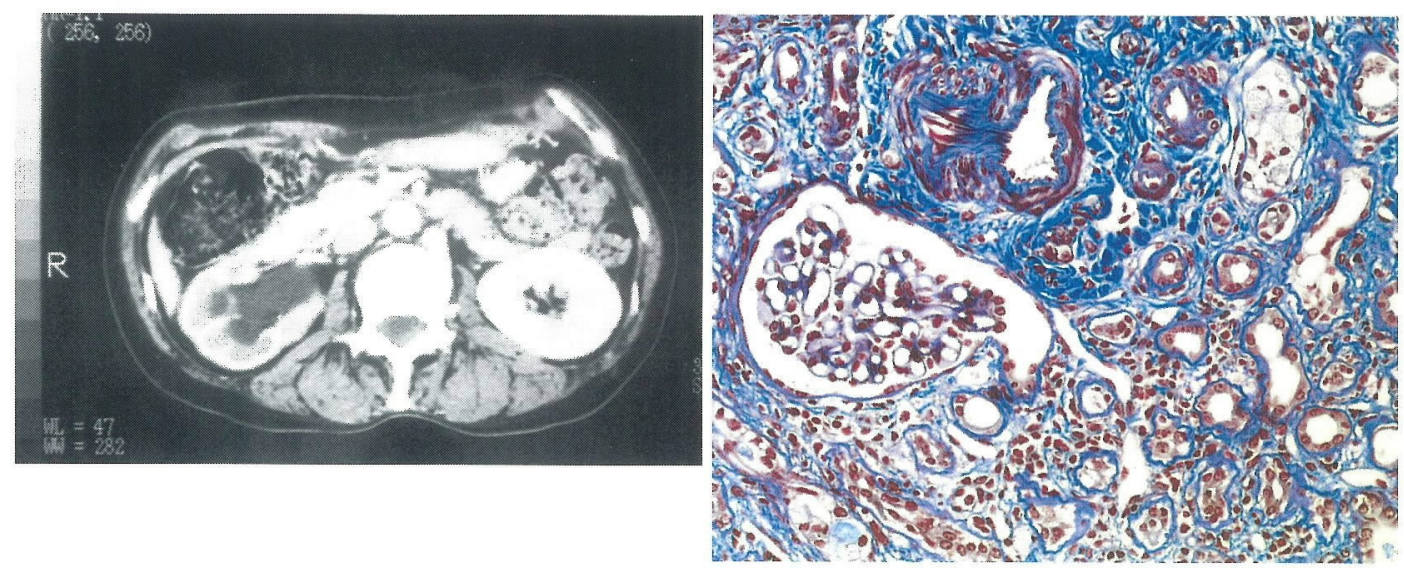

次の第二相（～5 時間)になると腎血流量は低下するが 尿管内压は引き続き上昇し $55 \mathrm{CmH}_{2} \mathrm{O}$ 前後にまで達す る.最後の第三相に至ると腎血流量はさらに低下し， 尿管内压も其に下降し始める ${ }^{201}$ 。第一相に扔ける一過 性の腎血流量の上昇の原因は，腎組織内圧の上昇が血 管抵抗の低下を招き一時的に輸出入細動脈が驰緩する ためと言われている"1．その後の輸入細動脈の収縮に

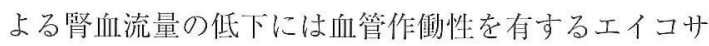
ノイド，特にトロンボキサン $\mathrm{A}_{2}$ の産生克進が强く関 与している21231.この過程はアンジオテンシン II に低 存性がある。閉塞性腎症の発症機序において最重要な 因子の一つが婜組織内压の上昇に伴うレニンーアンジ オテンシン系の活性化である(後述)。過剩に産生され たアンジオテンシン Iの刺激がその 1 型受容体 (AT1-R) と，それと共役する GTP 結合蛋白質 (G 蛋 白）とを介して糸球体絸胞内シグナル伝達を開始, ホ スフォリパーゼの活性化を通じてアラキドン酸を遊離 し，血管收縮作用を有するトロンボキサン $\mathrm{A}_{2}$ の産生 がえ進するとされている102211.

第三相は我々が䧗床的に観察する状態である。完全 閉塞であっても暫くの間は腎血流量はある程度保た れ, 系球体滤過と尿産生は僅かながら継続している。

IVPで淡いネフログラムが得られるのはこのためであ る。産生された尿は近位尿細管から再吸收され，一部 は腎㙉粘膜を通じて腎正リンパ系や腎而静脈系へ逆流 していく。腎乳頭円蓋部が破壊されると”腎㙉一集合管 逆流も生ずる251。小児水腎症の場合, 笃線維被裳に伸
展性を有するため巨大な水腎を星することが多いが, その割に腎機能が比較的保持されている症例がよく観 察される。仲展により腎組織内圧の上昇が緩和され， また搪張した腎外腎盎の粘膛からの逆流もあって腎血 流量と系永体滤過が保持されているためと思われる。

以上, 系球体レベルでの变化について述べたが, 閉 塞発症とともにまず尿細管間質に生ずる明らかな变化 は尿細管内圧（組織内圧）の上昇とそれに引き続く尿 細管周囲毛細血管への圧排，慢性の組織虚血状態であ る。この時期には尿細管一集合管内压の上昇により集 合管に抢ける水のチャンネル（アクアポリン）やヘン レ上行脚と集合管における $\mathrm{Na}$ 再吸収機構 $\left(\mathrm{Na}^{+}-\mathrm{K}^{+}-2 \mathrm{Cl}^{-}\right.$cotransporter, $\mathrm{Na}^{+}-\mathrm{K}^{+}$ATPase) が一時 的に障害される ${ }^{26(127)}$ 。雨僛性の閉塞の場合これを解除 すると, 細胞外液の斯留とも相まって暫くの間大量の 希䣋尿が排泗され続けることになる。一般に一側性の 閉塞の場合は対側腎による体液量の調節があるために 著しい閉塞解除後利㽷は見られないことが多いが, 閉 塞解除にともなう腎血流量の増加と尿細管内压の低下 が急激な系球体滤過の增加をもたらし，それに見合っ た尿縕管機能の回復が起こらない場合には低張性利尿 となって現れる ${ }^{281299}$. 再吸収機構が集中し, 従って酸 素消費量も多い近位尿細管は, 最も虚血々陵化ストレ スに弱くダメージを受けやすい部位である301.Yokoyamaが述べているように閉塞腎に招ける障害部位 に不均一性が存在するのもこの近位尿細管の脆弱性が 一因と思われる31! 
Table 1 アンジオテンシン II I 型，II 型受容体の局在と機能

I 型受容体は成人のほぼ全身に分布しているのに対して，II型受容体は胎生期に限って発現し ているものが殆どである，その作用は正反対で，腎に抢いてはI 型は障害的に，I型は保護的 に作用する。

\begin{tabular}{|c|c|c|}
\hline & I 型受容体 & II 型受容体 \\
\hline 腎臟 & $\begin{array}{c}\mathrm{Na}, \text { 水の再吸収促進 } \\
\text { 増殖促進 } \\
\text { 細胞外基質産生促進 }\end{array}$ & $\begin{array}{l}\text { 腎血管拡張 } \\
\text { 増殖抑制 }\end{array}$ \\
\hline 副腎 & $\begin{array}{c}\text { アルドステロン分泌促進（皮質） } \\
\text { カテコラミン遊離促進（䯣質） }\end{array}$ & - \\
\hline 循環器系 & $\begin{array}{l}\text { 血管収縮増強 } \\
\text { 血圧上昇 }\end{array}$ & $\begin{array}{l}\text { 血管収縮抑制 } \\
\text { 血圧低下 }\end{array}$ \\
\hline 尿路 & 尿管平滑筋の誘導 (胎生期) & 尿管芽の誘導（胎生期） \\
\hline 中枢神経 & $\begin{array}{c}\text { 交感神経活性化 } \\
\text { 抗利尿ホルモン分泌促進 }\end{array}$ & $\begin{array}{l}\text { 神経細胞の分化 } \\
\text { アポトーシス }\end{array}$ \\
\hline
\end{tabular}

閉塞腎における腎孟及び組織内圧の㠵進，それに伴 う腎内微小循環障害 (虚血) は組織中のレニンーアンジ オテンシン系の活性化を来す．循環血漿及び組織中の レニン活性，アンジオテンシン II 濃度が上昇，このア ンジオテンシン II の活性兄進が閉塞性腎症における 腎機能低下の一つの key factorである2 ${ }^{3233)}$. アンジオ テンシン II はその血管収縮による昇圧効果とアルド ステロン産生刺激とが知られているが，他にも腎に悪 影響を及ぼす様々な作用を有している ${ }^{34)}$ 。このホルモ ンは前述したトロンボキサン $\mathrm{A}_{2}$ の産生刺激に加え て，それ自体が引き金となって，細胞の増殖や分化を 制御するサイトカインである transforming growth factor- $\beta$ （TGF- $\beta$ )の発現を立進させる ${ }^{35)}$. TGF- $\beta$ は肝 硬変や肺線維症といった代表的な臓器線維症と同様 に ${ }^{36377}$ ，腎においても尿細管間質線維化の構成因子で ある collagen 等の細胞外基質を蓄積増加させる主因 子である ${ }^{38)}$.このように我々が基礎実験デー夕を基に 提唱してきた, 閉塞性腎症に扔いてレニンーアンジオテ ンシン系の活性化と TGF- $\beta$ の増加が重要な役割を担 うという知見はその後数多く追試され ${ }^{391 \sim 41)}$, 成書に も度々引用されている ${ }^{142243)}$. 我々は更に，これらの事 実がヒト閉塞腎においても同様に生じていることを確 認している ${ }^{16(4)}$.

アンジオテンシン II の受容体には I 型受容体と II 型受容体が知られており ${ }^{45}$ ，このような腎に悪影響を 及ぼす作用は I 型受容体を通じて発現される。アンジ オテンシン II が II 型受容体に結合すると全く正反対 の，血管拡張，血圧低下，細胞増殖抑制作用が生ずる
ことが明らかになってきたが46)，このII 型受容体の発 現分布は胎生期に有意でその後減少してしまゔ Ichikawa らはI 型，II 型それぞれの受容体のノックア ウトマウスを作成してその機能を解析している.アン ジオテンシン II は胎生期に I 型受容体を通じて尿路 の平滑筋を誘導，このシグナルが欠如すると腎孟腎杯 の発育不良と尿管蠕動の低下を来し，水腎症様の形態 をとる ${ }^{48491}$ 。また II 型受容体をノックアウトすると腎 孟尿管移行部狭窄, 低形成腎, 巨大尿管などの congenital anomalies of the kidney and urinary tract （CAKUT）を生じやすいことが判明した ${ }^{501511}$ 。このよ うにアンジオテンシン II は胎生期には 2 種の受容体 を通じて尿路の器官形成に貢献するが, 成熟すると I 型受容体が有意に残存，そのシグナルが過剩になると 様々な腎障害の key factor となる. Table 1 に現在ま でに判明している I 型, II 型受容体の機能を示した.

レニンーアンジオテンシン系の光進に加えて閉塞性 腎症の進展に重要なのは炎症性細胞浸潤である. 動物 実験に扔いても ${ }^{52}$ 臨床検体に㧈いても ${ }^{53}$ ，閉塞腎の腎 実質には非感染性の炎症性細胞，特に単核白血球の浸 潤が顕著に認められる。この浸潤は閉塞発症から数時 間後には確認されており, MCP-1 (Monocyte Chemoattractant Peptide-1), RANTES (Regulated upon Activation, Normal T cell Expressed and Secreted), MIP$1 \alpha$ (Macrophage Inflammatory Protein-1 $\alpha$ ) 等のケモ カインと ICAM-1 (Intercellular Adhesion Molecule-1) に代表される接着因子の発現充進とが誘引となってい $ろ^{5455)}$. 単核白血球は自ら分泌したケモカインにより 
図 2 組織への白血球浸潤

腎の毛細血管内を循環する白血球, 特に単球/マクロファージは走化性刺激により表面 に接着因子（Lymphocyte Function-Associated Antigen-1:LFA-1）を発現，血管内皮 細胞表面に発現した接着因子 (Intercellular Adhesion Molecule-1 : ICAM-1) と呼応し て内皮細胞表面にまず接着, 続いて回転しながら細胞間隙を通して間質領域へと漏出, 浸潤していく.

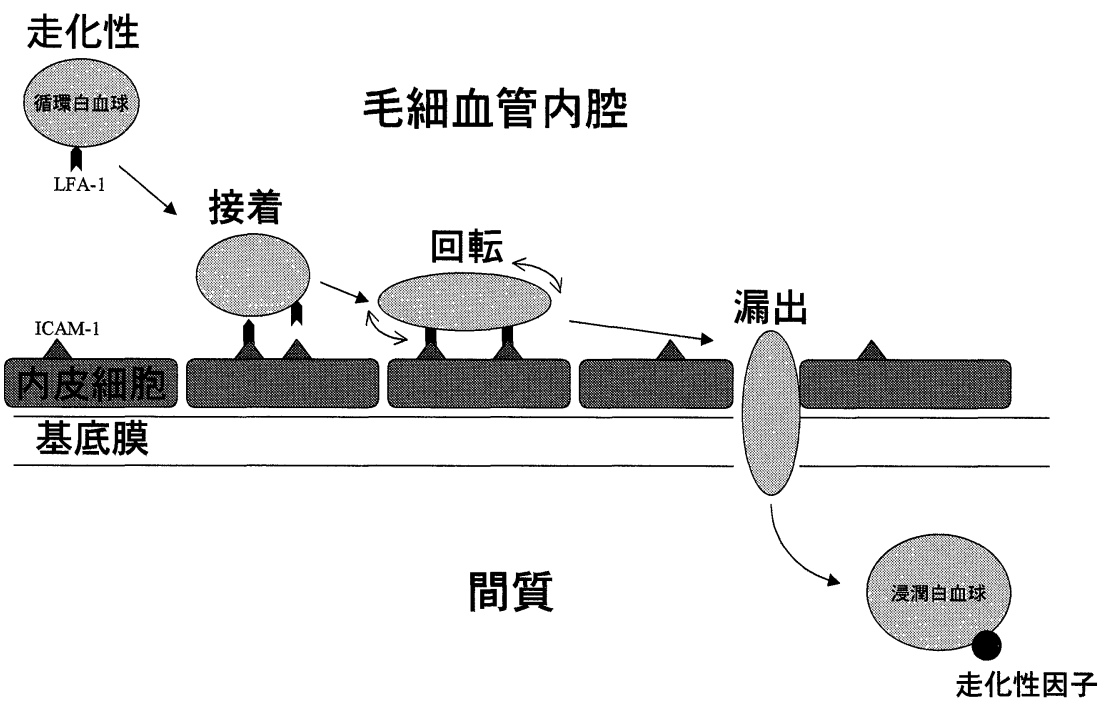

その表面に接着因子 integrin family に属する LFA-1 (Lymphocyte Function-associated Antigen-1), Mac1 (Macrophage antigen-1) を発現するようになる ${ }^{56)}$. 閉塞発症とともに血管内の単球やマクロファージ，Tリンパ球が遊走しながら (rolling) その表面に発現した LFA-1, Mac-1 と血管内皮上に発現した ICAM-1 との 接着（adhesion）を介して血管外の間質へ漏出（transmigration）していくことが判明している77（図 2). 閉 塞一組織内圧の上昇がなぜ短時間のうちにケモカイン を誘導するのかは詳しくは分かっていない，尿細管間 質に浸潤した単核白血球の役割は何であろうか. 単球/ マクロファージは TGF- $\beta$ をはじめ TNF $\alpha$ (Tumor Necrosis Factor $\alpha$ ), IL-1, IL-6 等多彩な炎症性サイトカイ ンや活性酸素を大量に分泌する能力を有する.しかし， 閉塞腎におけるマクロファージと TGF- $\beta$ による組織 二重染色では TGF- $\beta$ 産生細胞はマクロファージでな く尿細管等の腎本来の組織であった ${ }^{58)}$. 我々の実験で も，アンジオテンシン II 受容体拮抗剤投与によりラッ 卜閉塞性腎症は改善されたがマクロファージの浸潤は 増強したままであった ${ }^{32)}$. 閉塞性腎症の発症, 進展, 維 持のプロセスに扔いて単核白血球浸潤は TGF- $\beta$ 産生 以外の役割を有しているものと思われる.
腎線維化が進行するにあたっては, 線維化促進に作 用する因子 (TGF- $\beta$ 等) に加えて, 逆の線維化組織を 分解 (degrade) する因子も関与している．両者のバラ ンスの変動によって線維組織が増減していると言え る. 分解する側の因子の代表例として matrix metalloproteinases (MMP) と総称される collagenase や gelatinase 等の他, 線維素溶解作用を有する plasmin 等が 挙げられる ${ }^{59)}$. これらの蛋白分解酵素は癌の生物学で は浸潤を助長する悪玉であるが60), 臟器線維症におい ては蓄積された線維を分解してくれる善玉と言える. 閉塞腎においてはこの蛋白分解酵素の作用が抑制され てしまう。閉塞に伴って MMPを抑制する tissue inhibitor of metalloproteinases-1 (TIMP-1) ${ }^{61)}$ P plasmin を抑制する plasminogen activator inhibitor-1(PAI-1) ${ }^{62)}$ の活性が増強することも我々の実験で確認されてい る.

一酸化窒素 $(\mathrm{NO})$ の役割も重要である. 強力な血管 収縮，弛緩作用を有する対極の未知の二つの物質の存 在が以前から想定されていたが，前者は 1988 年に Yanagisawa 等によってエンドセリンとして発見さ れ ${ }^{63)}$ ，後者の正体は 1987 年に Moncada 等によって初 めて NO であることが突き止められた. $\mathrm{NO}$ は L-ア 
図 3 NO の腎保護作用

NO 合成酵素 (NOS)の働きによって L-アルギニンより生成された NO は糸球体内の細 胞外基質産生を抑制するだけでなく,グアニル酸サイクレースを活性化し, cGMPを上 昇させて糸球体毛細血管や輸入細動脈の内皮細胞を弛緩させ, 腎微小循環を改善する.

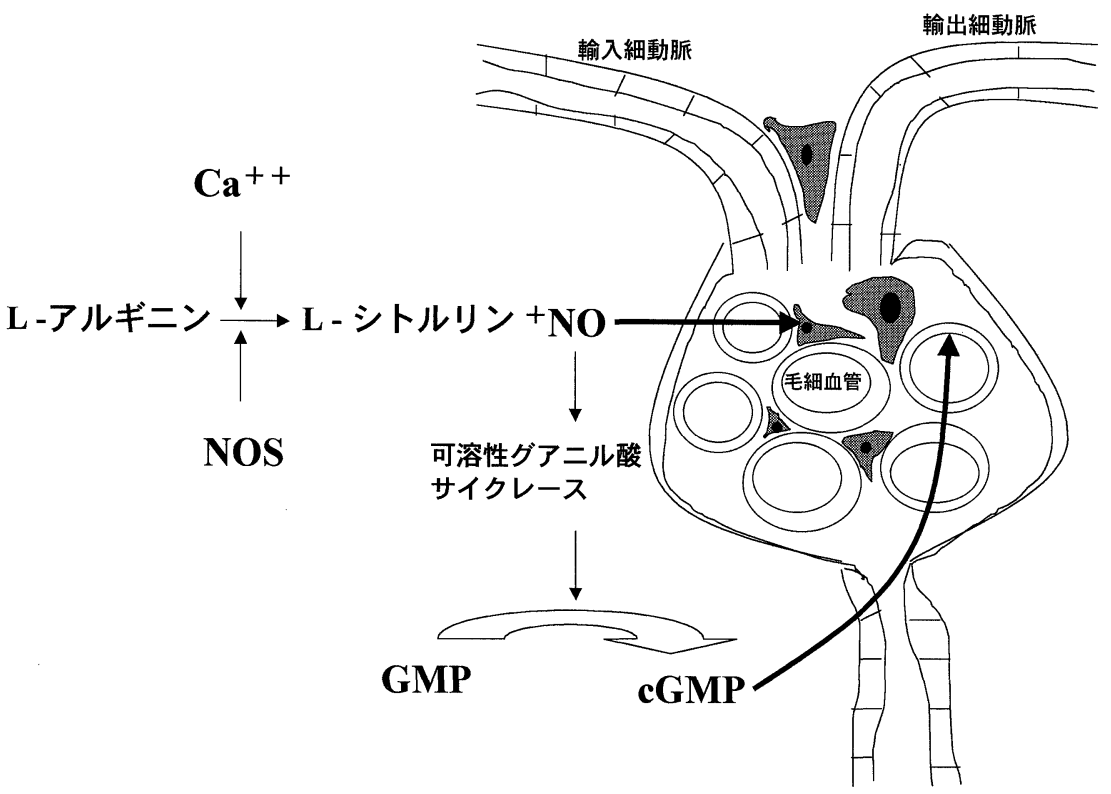

ルギニンを基質としてiNOS (inducible NO Synthase), cNOS (constitutive NO Synthase) 等の作用に より生ずるガスであり，受容体やチャンネルを介さず に組織に拡散していく．その血管弛緩作用は強力で, クエン酸シルデナフィルの作用機序もこの NO に因っ ている. NO は多彩な生理作用を有し, 現在まで腎に対 する作用は善玉，悪玉論が入り交じって多く議論され てきた．閉塞腎においては L-アルギニンの投与が組織 線維化を改善し ${ }^{65)}$ ，iNOS ノックアウトマウスではア ポトーシスがいっそう増悪することから，NOが閉塞 性腎症に対して腎保護的に作用することは確かなよう である(図 3) $)^{66)}$.

閉塞腎においては尿細管細胞のアポトーシスが立進 することも分かっている67).このアポトーシスが誘因 の一部となって尿細管萎縮や組織の㳖失が進むとされ ている.このアポトーシスの際の DNA 損傷に伴って p53 と p21 が増強して細胞周期の進行を抑制，DNA の修復に一役買っているらしい ${ }^{68)}$.

\section{Final Common Pathway}

以上述べてきたように，閉塞がいったん発生すると 尿細管内圧が上昇し，その後のプロセスは 1）組織の
虚血，2）ケモカインの発現に始まる単核白血球浸 潤，3）レニンーアンジオテンシン系の兄進，が誘導さ れ，後はほぼ一直線に，TGF- $\beta$ を介して細胞外基質が 蓄積していくという大きな流れで説明され得ることが 分かる。この流れ (pathway) は trigger が高血糖や免 疫複合体であればそれぞれ糖尿病性腎症や慢性糸球体 腎炎の形をとるものの基本的には共通で, 最近では Final Common Pathway と称されることが多い( ${ }^{69)}$. た だ，閉塞性腎症では最初に尿細管間質からダメージが 始まるが，糖尿病性腎症や慢性糸球体腎炎では糸球体 から始まるという違いはある. Final Common Pathway の概略を図 4 に示した.

\section{治療的側面}

\section{1. 閉塞解除}

閉塞性腎症の治療の第 1 は，当然のことながら initial trigger である尿細管内圧上昇の解除, 即ち閉塞の 機械的解除である．臨床的には腎孟形成術や尿管膀胱 新吻合術，内瘦や外瘦の留置が行われる．閉塞解除後 の腎機能の回復プロセスは基礎実験によって様々なア プローチで探求が行われてきた。解除により TGF- $\beta$ が低下し尿細管間質線維化が改善するという報告があ 
図 4 Final Common Pathway

各々の腎疾患は途中から共通の経路をたどる. 腎組織は最終的に線維化組織に置換さ れ，その機能を岥失する。

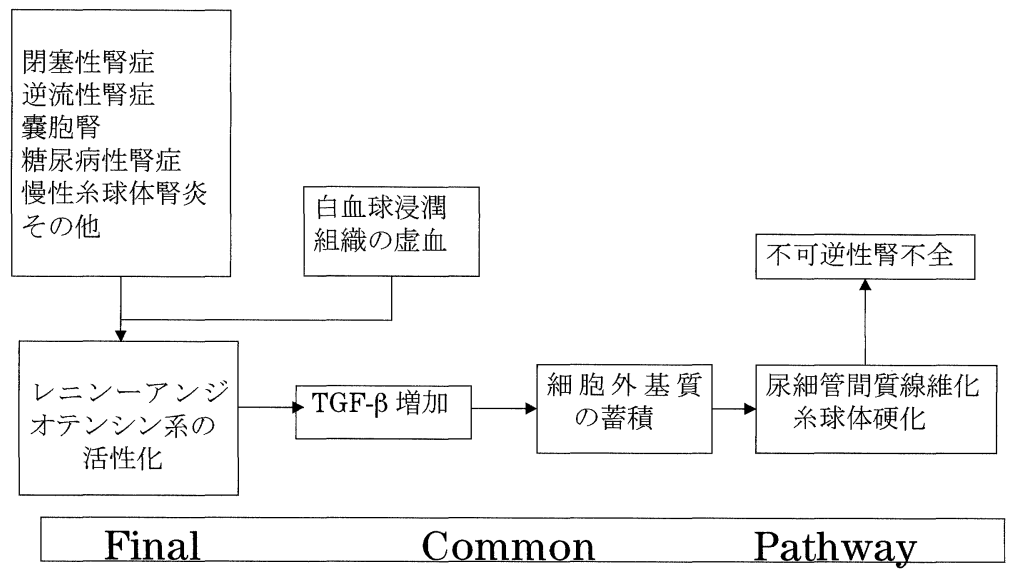

図 5 閉塞性腎症における薬物療法のターゲット

横軸に示す Final Common Pathway の種々の段階においてその Key Factor を阻害す る試みがなされている.

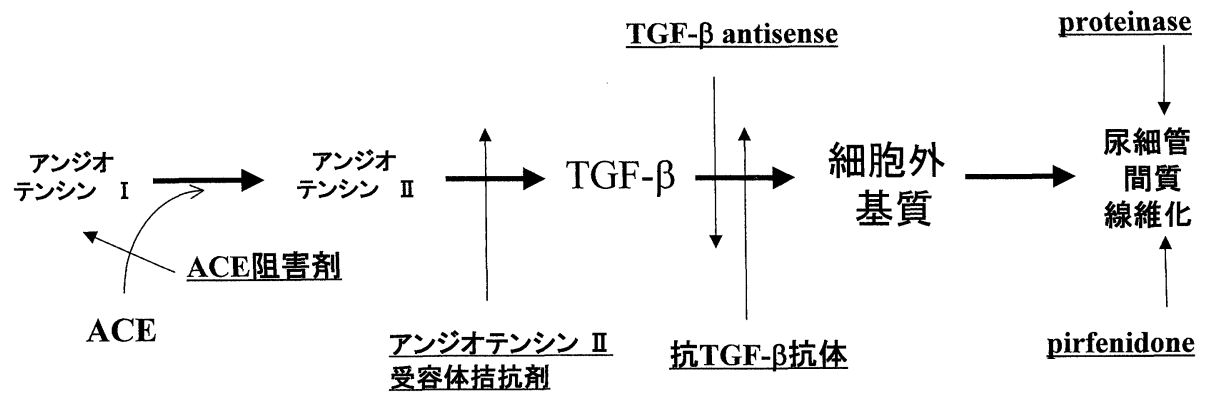

る一方で ${ }^{14)}$ ，TGF- $\beta$ は逆に上昇，アポトーシスも一段 と増強, 尿細管障害を惹起するとのデータもある ${ }^{70)}$. 興味深いのは幼弱ラットに実験的閉塞腎を作成し，そ の解除後の腎機能を検索した Chevalier らのグループ の成績である。これによると発育段階にある腎に閉塞 が生ずると，これを解除してもその後の発育はある程 度抑制され，その障害（糸球体硬化，尿細管間質線維 化）は成熟期まで持続する ${ }^{7172)}$ 。この事実は腎孟形成 術を施行された小児は成人になるまで腎機能の経過観 察が必要であることを示唆している.

2. 薬物療法

レニンーアンジオテンシン系の抑制

閉塞性腎症の進行抑制に対するに対するアンジオテ ンシン変換酵素阻害剤 (ACE 阻害剂) やアンジオテン
シン II 受容体拮抗剤の効果は我々の基礎実験で証明 され，数多く追試されている ${ }^{40) 73(74)}$. 興味深いのはこれ らの薬剂による腎保護作用は血圧の変化とは独立した 現象であること年，いったん形成された尿細管間質線 維化に対して, 遅延しての薬剤投与も有効であること である ${ }^{61)}$. ACE 阻害剤はアンジオテンシンIIから TGF- $\beta$ への流れを抑制する以外にも種々の腎保護作 用が知られている.アンジオテンシン II は輸出細動脈 を収縮させるが, ACE 阻害剂の投与はこの輸出細動脈 の拡張により（全身血圧と関係なく）系球体血圧を低 下させて腎を保護する。また，ACE 阻害剤はNO を増 強させる作用もあり，このNOを通じて腎微小循環の 改善の方向に働く. 当然のことながら Final Common Pathwayにおけるレニンーアンジオテンシン系のブ 
ロックは閉塞腎だけでなく他の多くの腎障害について も有効である。まず 2001 年に糖尿病性腎症に対して $\mathrm{ACE}$ 阻害剤イミダプリルが(高血圧合併の有無に関わ らず）腎疾患治療薬として保険収載された。

\section{TGF- $\beta$ 抑制}

Final Common Pathway における TGF- $\beta$ のポイン トでの抑制も多方面からアプローチされている．Miyajima 等はラット閉塞腎モデルにおいて抗 TGF- $\beta$ 抗 体を投与し，尿細管間質線維化とアポトーシスが抑制 されたと報告している ${ }^{75)}$. 大阪大学のグループはやは りラット閉塞腎モデルを用いて TGF- $\beta$ に対するアン チセンスオリゴデオキシヌクレオチドを拡張腎孟に注 入して逆行性に尿細管間質に取り込ませ，その線維化 を抑制出来たと述べている おいては遺伝子レベル, 蛋白レベルで TGF- $\beta$ をブロッ クして閉塞性腎症を改善させ得ることが示されてお り, 今後は他の多くの臟器線維症を含めて臨床応用へ 通じていくものと期待される.

\section{線維組織分解}

いったん生成された線維組織を分解させる試みもな されている，閉塞性腎症においては蛋白分解酵素阻害 剂である TIMP-1 ${ }^{61)}$ や PAI-1 ${ }^{62}$ の発現が立進するため, metalloproteinase や plasmin による細胞外基質蛋白 の分解が低下する．蛋白分解䤃素の補充や活性増強が 試行されている. また，最近注目されている物質に pirfenidone がある.この物質は作用機序ははっきりしな いものの，閉塞性腎症をはじめとする線維化組織を分 解する作用があるとされ77)，やはり今後の臨床応用が 期待されている.

\section{まとめ}

尿路の通過障害を放置すると腎が菲薄化していき， 機能が徐々に失われていく．この閉塞性腎症と称する 病態は泌尿器科的腎疾患の代表的なものであり, 当教 室では長年にわたってその病因病態の解明と治療に取 り組んできた. その結果, 源流 (initial trigger) は異なっ ていても腎臓の荒廃の過程は途中から大河（Final Common Pathway）に注ぐが如く共通であること，閉 塞性腎症の解明は即ち進行性腎不全の病態の解明であ ることが分かってきた．臨床的に腎機能の予後は糸球 体機能よりもむしろ尿細管機能に依存することが共通 認識となって以来, 従来泌尿器科医の専売特許であっ た閉塞腎モデルが現在では基礎医学や内科の領域でも 盛んに取り上げられるようになっている。しかし，こ れらの基礎実験で得られた多くの種子が臨床的に実を
結ぶまでには更なる研究の蓄積と進展が必要である.

稿を終えるに当たり，本テーマに取り組み続け指導して 下さった折笠精一名誉教授, 荒井陽一教授をはじめ諸先輩 方, 後輩諸子, そしてワシントン大学医療センターの Sauro Klahr 教授, Jeremiah Morrissey 教授に深甚なる謝意を表 します.

\section{文献}

1) Gulmi, F.A., Felsen, D. and Vaughan, E.D., Jr. : Pathophysiology of urinary tract obstruction. In Campbell's Ulology, 7th ed., p342-385,.Saunders Co., Philadelphia, 1998.

2）日本透析医学会統計調查委員会 同小委員会：わ が国の慢性透析療法の現況（2001 年 12 月 31 日現 在)。透析会誌, $36-1,1-31,2003$.

3）土田正義, 木村行雄, 菅原博厚, 染野 敬, 加藤義 朋：上部尿路機能の研究一第 9 報 先天性水腎症 における尿管機能．日泌会誌，57,1064-1071, 1966.

4）目時利林也：実験的水腎の走查電子顕微鏡による 観察. 日泌会誌，71, 1489-1499, 1980.

5）高橋 薫, 福崎 篤, 目時利林也, 西村洋介, 折笠 精一：上部尿路の Pressure-Flow Study一第 2 報 先天性水腎症の Pressure-Flow Study一，日泌会 誌, 78, 1559-1563, 1987.

6）近田龍一郎, 折笠精一, 庵谷尚正, 坂井清英, 久慈 了, 太田章三, 阿部優子, 池田成徳：小児一側性先 天性水腎症に打ける腎機能の推移一DMSA 腎摂 取率による分腎機能の検討一。日泌会誌，82 1576一1582, 1991.

7) Kaneto, H., Orikasa, S., Chiba, T. and Takahashi, $\mathrm{T}$. : Three-D muscular arrangement at the ureteropelvic junction and its changes in congenital hydronephrosis : A stereo-morphometric study. J. Urol., 146, 909-914, 1991.

8）折笠精一：先天性水腎症の基礎と臨床. 日泌会誌, 80 (13), 1875-1877, 1990.

9）折笠精一：尿路通過障害. ベッドサイド泌尿器科 学 診断治療編, 第 2 版, 569-572, 南江堂, 東京, 1991.

10) Klahr, S., Harris, K. and Purkerson, M.L. : Effects of obstruction on renal function. Pediatr. Nephrol., 2, 34-42, 1988.

11) Sharma, A.K., Mauer, M., Kim, Y. and Michael, A. Interstitial fibrosis in obstructive nephropathy. Kidney. Int., 44, 774-788, 1993.

12）鈴木省司, 福崎 篤, 折笠精一, 斉藤禎隆, 西山明 徳：リッサミングリーン注入法による一側完全尿 管閉塞腎の単一ネフロン機能の評価．日泌会誌, 78, 690-696, 1987 .

13）鈴木省司，福崎 篤，折笠精一，斉藤禎隆，西山明 
徳：一側完全尿管閉塞腎の閉塞開放後の系球体, 近位尿細管機能．日泌会誌，79, 654-659, 1988.

14) Ogata, Y., Ishidoya, S., Fukuzaki, A., Kaneto, H., Takeda, A. and Orikasa, S. : Upregulated expression of TGF- $\beta$, type IV collagen, plasminogen activator inhibitor-1 mRNA are decreased after release of unilateral ureteral obstruction. Tohoku J. Exp. Med., 197, 159-168, 2002.

15) Vaughan, E.D., Jr. and Gillenwater, J.Y. : Recovery following chronic unilateral ureteral occlusion : Functional, radiographic and pathologic alterations. J. Urol., 106, 27-35, 1971.

16) Ishidoya, S., Fukuzaki, A., Kaneto, H., Takeda, A., Ogata, Y., Sasaki, T., Suzuki, K., Watanabe, R., Hoshi, S., Kikuya, H., Takeuchi, K., Ito, S. and Orikasa, S. : Chronic unilateral ureteral obstruction represented as renin-dependent hypertension. Nephron, 85, 175-177, 2000.

17) Shapiro, S.R. and Bennett, A.H.: Recovery of renal function after prolonged unilateral ureteral obstruction. J. Urol., 115, 136-140, 1975.

18) Okubo, K., Suzuki, Y., Ishitoya, S. and Arai, Y. : Recovery of renal function after 153 days of complete unilateral ureteral obstruction. J. Urol., 160, 1422-1423, 1998.

19) Wright, F.S. : Effects of urinary tract obstruction on glomerular filtration rate and renal blood flow. Seminars in Nephrol., 2 (1) , 5-16, 1982.

20) Moody, T.E., Vaughan, E.D. Jr. and Gillenwater J. Y. : Relationship between renal blood flow and ureteral pressure 18 hours of total unilateral ureteral occlusion. Invest. Urol., 13, 246-251, 1975.

21) Nash, F.D. and Selkurt, E.E. : Effects of elevated ureteral pressure on renal blood flow. Circ. Res., 14 (15 suppl I), I142-I146, 1964.

22) Fukuzaki, A., Morrissey, J. and Klahr, S. : Enhanced glomerular eikosanoid production in the obstructed kidney. Int. Urol. Nephrol., 27, 783790, 1993.

23）畠山孝仁, 近田龍一郎, 太田章三, 久慈 了, 坂井 清英, 阿部優子, 千田尚毅, 折笠精一：一側性尿管 閉塞あるいは片腎摘出ラットに扔ける腎内 prostaglandin $\mathrm{E}_{2}$ おう び thromboxane $\mathrm{A}_{2}$ 局在の 変化. 日泌会誌, 89, 460-467, 1998.

24) Klahr, S. and Purkerson, M.L. : The pathophysiology of obstructive nephropathy : the role of vasoactive compounds in the hemodynamic and structual abnormalities of the obstructed kidney. Am.J. Kidney Dis., 23, 219 -223, 1994.

25) Stenberg, A., Bohman, S.O. and Morsing, P. : Back- leak of pelvic urine to the bloodstream. Acta. Physiol. Scand., 134, 223-234, 1988.

26) Frokiaer, J., Christensen, B.M., Marples, D., Djurhuus, J.C., Jensen, U.B., Knepper, M.A. and Nielsen, S. : Downregulation of aquaporin-2 parallels changes in renal water excretion in unilateral ureteral obstruction. Am.J. Physiol., 42, F213F223, 1997.

27) Harris, R.H. and Yarger, W.E. : The pathogenesis of post-obstructive diuresis.J. Clin. Invest., $56880-56887,1975$.

28）松下昌人：水腎症の研究一水腎尿中成分変化と腎 機能一. 日泌会誌，73, 904-916, 1982.

29）福崎 篤, 鈴木省司, 金藤博行, 岡田康弘, 折笠精 一: 偏側性水腎症に認められた閉塞解除後利尿. 西日泌尿，48, 73-79, 1986.

30) Kawada, N., Moriyama, T., Ando, A., Fukunaga, M., Miyata, T., Kurokawa, K., Imai, E. and Hori, M. : Increased oxidative stress in mouse kidneys with unilateral ureteral obstruction. Kidney Int., 56, 1004-1013, 1999.

31) Yokoyama, M., Seki, N., Oda, T., Takeuchi, M. and Tanada, S. : Recovery period from ureteral obstructions of different duration and severity in the rat kidney. Int.J. Urol., 1, 212-215, 1994.

32) Ishidoya, S., Morrissey, J., McCracken, R., Reyes, A. and Klahr, S. : Angiotensin II receptor antagonist ameliorates renal tubulointerstitial fibrosis caused by unilateral ureteral obstruction. Kidney Int., 47, 1285-1294, 1995.

33) Klahr, S., Ishidoya, S. and Morrissey, J. : Role of angiotensin II in the tubulointerstitial fibrosis of obstructive nephropathy. Am.J. Kidney Dis., 26, 141-146, 1995.

34) Ichikawa, I. and Harris, R.C.: Angiotensin actions in the kidney : Renewed insight into the old hormone. Kidney Int., 40, 583-596, 1991.

35) Kaneto, H., Morrissey, J. and Klahr, S. : Increased expression of TGF- $\beta$ mRNA in the obstructed kidney of rats with unilateral ureteral ligation. Kidney Int., 44, 313-321, 1993.

36) Gressner, A.M. : Transdifferentiation of hepatic stellate cells (Ito cells) to myofibroblasts: A key event in hepatic fibrogenesis. Kidney Int., 49, S39-S45, 1996.

37) McAnulty, R.J. and Laurent, G.J. : Pathogenesis of lung fibrosis and potential new therapeutic strategies. Exp. Nephrol., 3, 96-107, 1995.

38) Kaneto, H., Morrissey, J., McCracken, R., Reyes, A. and Klahr, S. : Enalapril reduces collagen type IV synthesis and expansion of the interstitium in the 
obstructed rat kidney. Kidney Int, 45, 1637-1647. 1994.

39) Pimentel, Jr., J.L., Montero, A., Wang, S., Yosipiv, I., El-Dahr, S. and Martinez-Meldonado, M. : Sequential changes in renal expression of reninangiotensin system genes in acute unilateral ureteral obstruction. Kidney Int., 48, 1247-1253, 1995.

40) Moriyama, T., Kawada, N., Akagi, Y., Ando, A., Horio, M., Yamauchi, A., Nagata, K., Imai, E. and Hori, M. : TCV-116 inhibits interstitial fibrosis and HSP 47 mRNA in rat obstructive nephropathy. Kidney Int., suppl. 63, s232-s235, 1997.

41) Fern, R.J., Yesko, C.M., Thornhill, B.A., Kim, H-S., Smithies, O. and Chevalier, R.L. : Reduced angiotensinogen expression attenuates renal interstitial fibrosis in obstructive nephropathy in mice. J. Clin. Invest., 103, 39-46, 1999.

42) Gulmi, F.A., Felsen, D. and Vaughan, E.D., Jr. : Pathophysiology of urinary tract obstruction. In Campbell's Urology, 8th ed., p411-456, Saunders Co., Philadelphia, 2002.

43) Kelly, C.J. and Neilson, E.G. : Tubulointerstitial Diseases. In Brener \& Rector's The Kidney., 6th ed., p1509-1536, Saunders Co., Philadelphia, 2000.

44) Kaneto, H., Ohtani, H., Fukuzaki, A., Ishidoya, S., Nagura, H. and Orikasa, S. : Increased expression of TGF- $\beta$ but not its receptors is associated with interstitial changes of human kidney with ureteral obstruction. Kidney Int., 56, 2137-2146, 1999.

45) Bernstein, K.E. and Berk, B.C. : The biology of angiotensin II receptors. Am.J. Kidney Dis., 22, 745-754, 1993.

46) Nakajima, M., Hutchinson, H.G., Fujinaga, M., Hayashida, W., Morishita, R., Zhang, L., Horiuchi, M., Pratt, R.E. and Dzau, V.J. : The angiotensin II type $2\left(\mathrm{AT}_{2}\right)$ receptor antagonizes the growth effects of the $\mathrm{AT}_{1}$ receptor : Gain-of-function study using gene transfer. Proc. Natl. Acad. Sci. USA., 92, 10663-10667, 1995.

47) Sechi, L.A., Grady, E.F., Griffin, C.A., Kalinyak, J.E. and Schambelan, M. : Distribution of angiotensin II receptor subtypes in rat and human kidney. Am.J. Physiol., 262, F236-F240, 1992.

48) Miyazaki, Y., Tsuchida, S., Nishimura, S., Pope, IV, J.C., Harris, R., McKanna, J. M., Inagami, T., Hogan, B.L.M., Fogo, A. and Ichikawa, I. : Angiotensin induces the urinary peristaltic machinery during the perinatal period. J. Clin. Invest., 102, 1489-1497, 1998.
49) Miyazaki, Y., Tsuchida, S., Fogo, A. and Ichikawa, $\mathrm{I}$. : The renal lesions that develop in neonatal mice during angiotensin inhibition mimic obstructive nephropathy. Kidney Int., 55, 1683-1695, 1999.

50) Yerkes, E., Nishimura, S., Miyazaki, Y., Tsuchida, S., Brock, III, J.W. and Ichikawa, I. : Role of angiotensin in the congenital anomalies of the kidney and urinary tract in the mouse and the human. Kidney Int., 54, s75-s77, 1998.

51) Nishimura, S., Yerkes, E., Hohenfellner, K., Miyazaki, Y., Ma, J., Hunley, T.E., Yoshida, H., Ichiki, T., Threadgill, D., Phillips, III, J.A., Hogan, B.M.L., Fogo, A., Brock, III, J.W., Inagami, T. and Ichikawa, I. : Role of angiotensin type 2 receptor gene in congenital anomalies of the kidney and urinary tract, CAKUT, of mice and men. Molecular Cell, 3, 1-10, 1999.

52) Schreiner, G.F., Harris, K.P.G., Purkerson, M.L. and Klahr, S. : The immunological aspects of acute ureteral obstruction : immune cell infiltrate in the kidney. Kidney Int., 34, 487-493, 1988.

53) Ishidoya, S., Takyu, S., Yoshikawa, K., Ogata, Y., Takeda, A., Sasaki, T., Yamada, S. and Fukuzaki, A. : Mononuclear leukocyte infiltration in human obstructive nephropathy. J. Urol., 167 (4), 95, 2002.

54）金藤博行, 福崎 篤, 石戸谷滋人, 竹田篤史, 尾形 幸彦, 佐々木亨, 山田成幸, 折笠精一: ラット尿管 閉塞腎に打ける chemokineの mRNA 発現. 日泌 尿会誌，91（2），69-74, 2000.

55) Ricardo, S.D., Levinson, M.E., DeJoseph, M.R. and Diamond, J.R. : Expression of adhesion molecules in rat renal cortex during experimental hydronephrosis. Kidney Int., 50, 2002-2010, 1996.

56) Takeda, A., Fukuzaki, A., Kaneto, K., Ishidoya, S., Ogata, Y., Sasaki, T., Konda, R., Sakai, K. and Orikasa, S. : Role of leukocyte adhesion molecules in monocyte/macrophage infiltration in weanling rats with unilateral ureteral obstruction. Int.J. Urol., 7, 415-420, 2000.

57) Brady, H.R. : Leukocyte adhesion molecules and kidney diseases. Kidney Int., 45, 1285-1300, 1994.

58) Yamamoto, T., Noble, N.A., Miller, D.E. and Border, W.A. : Sustained expression of TGF- $\beta 1$ underlies development of progressive kidney fibrosis. Kidney Int., 45, 916-927, 1994.

59) Mignatti, P. : Extracellular matrix remodeling by metalloproteinases and plasminogen activators. Kidney Int., 47, s12-s14, 1995.

60) Itoh, Y., and Nagase, H. : Matrix metalloproteinases in cancer. Essays Biochem., 38, 21-36, 2002.

61) Ishidoya, S., Morrissey, J., McCracken, R. and 
Klahr, S. : Delayed treatment with enalapril halts tubulointerstitial fibrosis in rats with obstructive nephropathy. Kidney Int., 49, 1110-1119, 1996.

62) Ishidoya, S., Ogata, Y., Fukuzaki, A., Kaneto, H., Takeda, A. and Orikasa, S. : Plasminogen activator inhibitor-1 (PAI-1) and tissue-type plasminogen activator（t-PA） are upregulated during unilateral ureteral obstruction in adult rats.J. Urol., 167 (3), 1503-1507, 2002.

63) Yanagisawa, M., Kurihara, H., Kimura S., Tomobe, Y., Kobayashi, M,Mitsui, Y., Yazaki, Y., Goto, K. and Masaki, T. : A novel potent vasoconstrictor peptide produced by vascular endothelial cells. Nature, 332 (6163), 411-415, 1988.

64) Palmer, R.M., Ferrige, A.G. and Moncada, S. : Nitric oxide release accounts for the biological activity of endothelium-derived relaxing factor. Nature, 327 (6122), 524-526, 1987.

65) Morrissey, J., Ishidoya, S., McCracken, R. and Klahr, S. : Nitric oxide generation ameliorates the tubulointerstitial fibrosis of obstructive nephropathy. J. Am. Soc. Nephrol., 7, 2202-2212, 1996.

66) Miyajima, A., Chen, J., Poppas, D.P., Vaughan, Jr., D. and Felsen, D. : Role of nitric oxide in renal tubular apoptosis of unilateral ureteral obstruction. Kidney Int., 59, 1290-1303, 2001.

67) Chevalier, R.L., Smith, C.D., Wolstenholme, J., Krejewski, S. and Reed, J.C. : Chronic ureteral obstruction in the rat suppresses renal tubular Bcl-2 and stimulates apoptosis. Exp. Nephrol., 8 (2), 115-122, 2000.

68) Morrissey, J., Ishidoya, S., McCracken, R. and Klahr, S. : Control of p53 and p21 (WAF1) expression during unilateral ureteral obstruction. Kidney int., 50 (Suppl 57), s84-s92, 1996.

69) Weber, K.T. : Fibrosis, a common pathway to organ failure: Angiotensin II and tissue repair.
Seminars Nephrol., 17 (5), 467-491, 1997.

70) Oka, A., Tanji, N., Toshino, A., Miyauchi, Y. and Yokoyama, M. : Expression of growth factors after release of ureteral obstruction in the rat kidney. Int.J. Urol., 6, 607-615, 1999.

71) Chevalier, R.L., Kim, A., Thornhill, B.A. and Wolstenholme, J.T. : Recovery following relief of unilateral ureteral obstruction in the neonatal rat. Kidney Int., 55, 793-807, 1999.

72) Chevalier, R.L., Thornhill, B.A., Chang, A.Y., Cachat, F. and Lackey, A. : Recovery following release of ureteral obstruction in the rat: relationship to nephrogenesis. Kidney Int., 61, 20332043, 2002.

73) Chevalier, R.L., Thornhill, B.A. and Wolstenholme, J.T. : Renal cellular response to ureteral obstruction : Role of maturation and angiotensin II. Am.J. Physiol., 277, F41-F47, 1999.

74) Jones, E.A., Shahed, A. and Shoskes, D.A. : Modulation of apoptotic and inflammatory genes by bioflavonoids and angiotensin II inhibition in ureteral obstruction. Urology, 56, 346-351, 2000.

75) Miyajima, A., Chen, J., Lawrence, C., Ledbetter, S., Soslow, R.A., Stern, J., Jha, S., Pigat, J., Lemer, M. L., Poppas, D.P., Vaughan, Jr., D. and Felsen, D. : Antibody to transforming growth factor- $\beta$ ameliorates tubular apoptosis in unilateral ureteral obstruction. Kidney Int., 58, 2301-2313, 2000.

76) Isaka, Y., Tsujie, M., Ando, Y., Nakamura, H., Kaneda, Y., Imai, E. and Hori, M. : Transforming growth factor- $\beta 1$ antisense oligodeoxynucleotides block interstitial fibrosis in unilateral ureteral obstruction. Kidney Int., 58, 1885-1892, 2000.

77) Shimizu, T., Kuroda, T., Hata, S., Fukagawa, M., Margolin, S.B. and Kurokawa, K. : Pirfenidone improves renal function and fibrosis in the postobstructed kidney. Kidney Int., 54, 99-109, 1998. 